\title{
Erlotinib augmentation with dapsone for rash mitigation and increased anti-cancer effectiveness
}

\author{
R. E. Kast ${ }^{*}$
}

\begin{abstract}
Background: The epidermal growth factor receptor tyrosine kinase inhibitor erlotinib has failed in many ways to be as potent in the anti-cancer role as pre-clinical studies would have suggested. This paper traces some aspects of this failure to a compensatory erlotinib-mediated increase in interleukin-8. Many other-but not all- cancer chemotherapeutic cytotoxic drugs also provoke a compensatory increase in a malignant clone's interleukin-8 synthesis. Untreated glioblastoma and other cancer cells themselves natively synthesize interleukin-8. Interleukin-8 has tumor growth promoting, mobility and metastasis formation enhancing, effects as well as pro-angiogenesis effects.

Findings: The old sulfone antibiotic dapsone- one of the very first antibiotics in clinical use- has demonstrated several interleukin-8 system inhibiting actions. Review of these indicates dapsone has potential to augment erlotinib effectiveness. Erlotinib typically gives a rash that has recently been proven to come about via an erlotinib triggered up-regulated keratinocyte interleukin-8 synthesis. The erlotinib rash shares histological features reminiscent of typical neutrophilic dermatoses. Dapsone has an established therapeutic role in current treatment of other neutrophilic dermatoses.
\end{abstract}

Conclusion: Thus, dapsone has potential to both improve the quality of life in erlotinib treated patients by amelioration of rash as well as to short-circuit a growth-enhancing aspect of erlotinib when used in the anti-cancer role.

Keywords: Dapsone, Erlotinib, Glioblastoma, Interleukin-8, Ovarian cancer, Neutrophils, Non-small cell lung cancer, Pancreas cancer, Rash, Quality of life

Prelude: In chess, all moves create weaknesses and strengths.

\section{Background}

This paper points to a simple drug addition to erlotinib that is planned to make erlotinib both better tolerated and more effective in the anti-cancer role. Erlotinib is a 393 Da tyrosine kinase inhibitor with specific activity for the epidermal growth factor receptor [EGFR] also termed HER-1 (Zahonero and Sanchez-Gomez 2014). Rash, diarrhea, and fatigue are common side effects (Tiseo et al. 2014). The typical erlotinib rash can be quite bothersome in a significant minority of those treated, lowering quality of life (Tiseo et al. 2014). Erlotinib has been shown

*Correspondence: richarderickast@gmail.com

IIAIGC Study Center, 22 Church Street, Burlington, VT 05401, USA to prolong overall survival in non-small cell lung cancer (D'Arcangelo and Cappuzzo 2013; Pallis and Syrigos 2013; Zhang et al. 2012) and pancreatic cancer with gemcitabine (Zahonero and Sanchez-Gomez 2014; Park et al. 2013; Vaccaro et al. 2013) or with capecitabine (López et al. 2013), indications for which it is widely used and approved by national regulatory authorities. However, in pre-treated patients median overall survival (OS) is less than a year in both pancreas cancer (Vaccaro et al. 2013; López et al. 2013; Stepanski et al. 2013) and in non-small cell lung cancer (Van Meerbeeck et al. 2014; Kaburagi et al. 2013).

Good tumor suppressive effects in head and neck cancer is typically associated with rash or mucositis in a third of treated patients (Gross et al. 2014). Erlotinib has useful effects like this in several cancers when used "off-label",

\section{Springer}

(c) 2015 Kast. This article is distributed under the terms of the Creative Commons Attribution 4.0 International License (http:// creativecommons.org/licenses/by/4.0/), which permits unrestricted use, distribution, and reproduction in any medium, provided you give appropriate credit to the original author(s) and the source, provide a link to the Creative Commons license, and indicate if changes were made. 
for example, muscle invasive bladder cancer can be significantly down-staged after 4 weeks preoperative erlotinib (Pruthi et al. 2010). With erlotinib (plus bevacizumab) in advanced platinum-resistant epithelial ovarian cancer [EOC] $70 \%$ of patients progressed by 6 months (Chambers et al. 2010). Glioblastoma patients treated at first recurrence with erlotinib had a median 10 month overall survival with $20 \%$ of treated patients experiencing severe rash (Yung et al. 2010). When treating recurrent glioblastoma, erlotinib at $150 \mathrm{mg}$ daily gives a 3 month progression-free survival and 9 month overall survival (Peereboom et al. 2010). Recent study of erlotinib with temsirolimus gave no better results (Wen et al. 2014). In selected good-prognosis post-resection, post-radiation (but never chemotherapy) glioblastoma patients, daily erlotinib gave a $3 \%$ non-progression at 6 months and $40 \%$ death at one year (Raizer et al. 2010). Erlotinib monotherapy in recurrent glioblastoma gave a median 7 month OS (Kesavabhotla et al. 2012).

The high incidence of EGFR overexpression in pediatric high grade gliomas (Zahonero and Sanchez-Gomez 2014) provided the rationale for conducting a pediatric study using EGFR inhibitors. The use of erlotinib during and after local radiotherapy did not change the poor outcome of children with intracranial high grade gliomas (Qaddoumi et al. 2014). The combination of erlotinib and rapamycin, an mTOR inhibitor, for recurrent low grade glioma patients was, in general, well tolerated but had questionable to no activity (Yalon et al. 2013). Clearly, erlotinib needs help.

Why erlotinib has not been more effective even in the presence of overexpression of EGFR, remains unclear (Zahonero and Sanchez-Gomez 2014) but a crucial question to answer. This paper now attempts a contribution to that answer.

Cells generally, and cancer cells specifically, are not passive recipients of therapeutic interventions. They react. As in the Preamble, interventions commonly and inherently generate reactions with effect opposing the original intent. In cancer treatment, this means reactions with potential to enhance tumor growth. This paper addresses one such compensatory growth-enhancing reaction- the elevation of interleukin-8 (IL-8) by erlotinib. The reviewed data will show how erlotinib-provoked IL-8 elevation has three negative effects on treatment efforts: (1) decreasing quality of life by generation of the neutrophilic erlotinib rash, (2) IL-8 mediated enhanced migration or invasion of cancer cells in a similar manner as has been shown for neutrophils' chemotaxis along an IL-8 gradient, and (3) enhanced neutrophil migration to and into tumors with ensuing growth contribution by factors brought to tumors by these neutrophils.

Past research leads to a conclusion that the old antiHansen's disease sulfone antibiotic dapsone, when added to erlotinib, can be expected to mitigate all three IL-8-related erlotinib consequences that currently detract from erlotinib's anti-cancer effectiveness.

\section{The erlotinib rash}

IL-8 (synonymous with CXCL-8) is an inflammationmediating, pro-angiogenic, $\sim 8 \mathrm{kDa}$ cytokine/chemokine, signaling via CXCR1 or CXCR2 receptors (Gales et al. 2013; Baggiolini et al. 1995). IL-8 is synthesized by normal cells, particularly keratinocytes, and by dozens of cancer types where it is involved in, and contributes to, several domains of cancer pathophysiology (Gales et al. 2013; Lippitz 2013). IL-8 is central to both normal and pathogenic angiogenesis (Desbaillets et al. 1997).

Development of rash during erlotinib treatment is a common occurrence. Typical erlotinib rashes are pleomorphic, appearing clinically as pruritic or nonpruritic papules, pustules, xerodermia, or paronychia (Kiyohara et al. 2013). In confirming earlier studies of Nardone et al., in 2012, Bangsgaard et al. showed unequivocally that an iatrogenic erlotinib rash experimentally induced in healthy human volunteers was caused by IL- 8 mediated neutrophil infiltration (Nardone et al. 2010; Bangsgaard et al. 2012). This would put erlotinib rashes solidly within the neutrophilic dermatoses' category (Wallach and Vignon-Pennamen 2006) - a category in which dapsone has a long clinical history for being effective (Paniker and Levine 2001; Wozel and Blasum 2014; Cohen 2009).

Depending on dosing and study conditions, erlotinib rash can be seen in 75-90\% of treated patients, being severe in $\sim 10 \%$ (Tan and Chan 2009; Jia et al. 2009; Rozensztajn et al. 2014) This rash is usually treated with topical antibiotics, meticulous skin care, minocycline and topical steroids (Kiyohara et al. 2013). Development of an erlotinib rash confers clear but minor overall survival advantage when treating various cancers (Stepanski et al. 2013; Kaburagi et al. 2013; Peereboom et al. 2010; Kiyohara et al. 2013; Aranda et al. 2012; Petrelli et al. 2012; Fiala et al. 2013) with some indication that greater rash severity is correlated with slightly longer OS than lesser severity rashes (Kiyohara et al. 2013; Rozensztajn et al. 2014; Petrelli et al. 2012) A statistically significant association exists between higher erlotinib levels and greater likelihood of rash (Tiseo et al. 2014; Fukudo et al. 2013).

Erlotinib is not unique in stimulating IL-8 synthesismany cancer chemotherapeutic drugs do. Urothelium exposed to doxorubicin at levels used in intravesical treatment triggered IL-8 synthesis (Kang et al. 2013). Paclitaxel and temozolomide doubled IL-8 synthesis in melanoma cells (Luo et al. 2012). 5-Fluorouracil (5-FU) induced IL-8 upregulation in prostate cancer cells, an effect mediated by IL-8 signaling at CXCR2 (Wilson et al. 2008a). Most importantly for the proposed role for dapsone, in that study direct 5-FU cytotoxicity reduction by that compensatory IL- 8 increase could be mitigated by an experimental CXCR2 blocker (Wilson et al. 
2008b), an effect expected to be duplicated by dapsone. Oxaliplatin induced increased IL-8 in metastatic prostate cells (Wilson et al. 2008a). Irradiation, 5-FU and cisplatin each individually triggered an increase in IL-8 in head and neck cancer cell lines (Reers et al. 2013). Topotecan increased IL-8 in breast cancer (Wan et al. 2012). Melanoma cells naturally secrete abnormally high levels of IL-8, levels that further increase after exposure to etoposide or doxorubicin (Merighi et al. 2009). Even the surgery of EOC resection can trigger systemic increase in IL-8 (Dong et al. 2012). It is reasonable to assume that, were dapsone to indeed decrease IL-8 signaling, and its consequences, during erlotinib treatment, dapsone could find wide applicability in augmenting other cancer chemotherapies that engage compensatory increases in IL-8.

Thus, elevation of IL- 8 seems to be a common-but not universal- attribute of cytotoxic chemotherapy drugs. Why rash is more common with erlotinib remains unexplained. IL-8 elevations in untreated cancer and its further elevation by cancer chemotherapies are examples of the Preamble chess aphorism that indeed apply to medicine.

\section{Dapsone}

Dapsone is a $248 \mathrm{Da}$ antibiotic introduced into clinical practice in the late 1940s and still used worldwide. Dapsone is active against, and used clinically to treat various species of Pneumocystis, Plasmodia, Toxoplasma, and Mycobacteria (Paniker and Levine 2001; Coleman 1993. Dapsone level is typically $2-5$ microg/mL serum after single dose (Opravil et al. 1994; Swain et al. 1983). Time to Cmax is $\sim 4 \mathrm{~h}, \mathrm{~T} 1 / 2$ about $30 \mathrm{~h}$, with significant variability and enterohepatic circulation (Zuidema et al. 1986). Therapeutic serum levels are thought to be between 0.5 and $5 \mathrm{microg} / \mathrm{mL}$ when used in antibiotic and anti-protozoa roles (Zuidema et al. 1986). Optimal blood levels when treating neutrophilic dermatoses have not been determined. CNS penetration of dapsone is excellent, cerebrospinal fluid levels reaching $50-100 \%$ of serum levels (Rich and Mirochnick 1996), a particularly valuable attribute when treating glioblastoma. Although most sulfonamide allergic patients tolerate dapsone without problem, dapsone inhibits dihydrofolic acid synthesis by competing with para-aminobenzoic acid for the active site of dihydropteroate synthetase, preventing conversion of para-aminobenzoic acid to dihydrofolic acid (Coleman 1993) as do sulfonamides.

Independently of its antibiotic attributes, dapsone is active in treating autoimmune bullous diseases (Piette and Werth 2012) and neutrophilic dermatoses (Paniker and Levine 2001; Wozel and Blasum 2014; Cohen 2009). In bullous pemphigoid dapsone stops bullae formation and often the rash but does not affect the underlying sub-epidermal auto-antibody fixation (Booth et al. 1992; Kasperkiewicz and Zillikens 2007; Shimanovich et al. 2004). But dapsone does stop the consequent IL-8 mediated recruitment of neutrophils to areas of autoantibody deposition. Thereby dapsone stops bullae formation (Booth et al. 1992; Kasperkiewicz and Zillikens 2007; Shimanovich et al. 2004). Given the work of Nardone et al. and of Bangsgaard et al. quoted above (Nardone et al. 2010; Bangsgaard et al. 2012) and the action of dapsone in autoimmune bullous diseases, in like manner dapsone will mitigate erlotinib rashes.

Of crucial importance to this intended use, dapsone inhibits LPS stimulated IL-8 production in human keratinocytes (Schmidt et al. 2001). IL-8 synthesis was also reduced both in LPS stimulated bronchial epithelial cells in vitro (Kanoh et al. 2011), and in LPS stimulated peripheral blood mononuclear cells (Abe et al. 2008). Dapsone quantitatively reduced mRNA expression of endothelin-1 (ET-1), macrophage inflammatory protein-1 alpha (MIP-1 alpha), and transforming growth factor-beta (TGF-beta) in a mouse model of paraquat lung injury (Cho et al. 2011). ET-1 (Kast 2009; Liu et al. 2011; Patel and McKeage 2014; Paolillo et al. 2010), MIP-1 (Fang et al. 2011; Weigert et al. 2009 and TGFbeta (Hau et al. 2011; Joseph et al. 2013) are, all three to varying degrees, shown to contribute to many cancers' growth and treatment resistance, including glioblastoma (Fang et al. 2011; Stiles et al. 1997) and EOC (Kast 2009; Vergara et al. 2010). A crucial question for determining dapsone's potential in the anti-cancer role would be to determine if these mRNA reductions are a primary effect of dapsone or a secondary effect to action at a paraquatspecific trigger to these mRNA elevations.

Dapsone has already been suggested as an adjunct to glioblastoma treatment by blocking IL-8 directed migration of neutrophils into tumor, thereby lowering neutrophil-delivered VEGF to a growing glioblastoma (Kast et al. 2011, 2012). As an ancillary benefit, by inhibiting 5-lipoxygenase (5-LOX), dapsone diminishes leukotriene synthesis (Wozel and Blasum 2014; Wozel and Lehmann 1995). 5-LOX products contribute to growth in glioblastoma (Morin et al. 2013; Ishii et al. 2009) and other cancers (Bishayee and Khuda-Bukhsh 2013; Meng et al. 2013; Wen et al. 2015).

\section{IL-8}

IL-8 upregulation is a native feature of many cancers, forming an active growth facilitating factor for these cancers (Gales et al. 2013; Shi et al. 2001; Campbell et al. 2013). Yet more central to cancer physiology, IL-8 forms a stronger growth enhancing role in the stem sub-population than in the non-stem population in breast cancer (Singh et al. 2013a, 2013b) hepatocellular carcinoma 
(Tang et al. 2012), squamous head/neck cancer (Chikamatsu et al. 2011), glioblastoma, (Infanger et al. 2013; Bonavia et al. 2012) and others.

Exogenous IL-8 stimulated EOC cell line proliferation in vitro (Wang et al. 2005, 2011; Merritt et al. 2008; Wang et al. 2012). By immunohistochemistry only half of EOC patient biopsies were positive for high IL-8 expression, with higher expression correlating with shorter overall survival (Merritt et al. 2008). Although confirming EOC synthesis of IL-8 using immunohistochemistry of EOC surgical resection tissue, others found no relationship between staining intensity and OS (Browne et al. 2013).

By in vitro hybridization in EOC biopsies IL-8 mRNA was found to be overexpressed (Davidson et al. 2003). EOC cell lines synthesize and secrete IL-8, with more IL-8 being synthesized in estrogen receptor negative cell lines, less in estrogen receptor positive lines (Davidson et al. 2003). Serum IL-8 levels were higher in EOC than in controls (Lokshin et al. 2006; Autelitano et al. 2012), with higher levels predicting shorter OS (Bertenshaw et al. 2008; Dobrzycka et al. 2013; Kassim et al. 2004). EOC tumor associated macrophages have the ability to stimulate EOC cells' IL-8 synthesis (Wang et al. 2013). EOC migration and invasion is stimulated by omental adipocytes, an effect largely mediated by IL-8 (Nieman et al. 2011).

EOC cell migration along an IL-8 gradient (Ma et al. 2011) is reminiscent of similar findings of neutrophil chemotaxis along an IL-8 gradient. Since solid data shows dapsone blinding of neutrophils' migration along an IL-8 gradient, similar blinding by dapsone of EOC cells can be expected. IL-8 figures prominently in the typical intense neovascularization in EOC (Yang et al. 2010).

In vitro EOC resistance to cisplatin and paclitaxel is enhanced by exogenous IL-8 (Wang et al. 2011). Epinephrine or norepinephrine exposure resulted in more than doubling of IL-8 protein and mRNA in EOC cells, with even greater increases in the IL-8 promoter, effects that were all blocked by propranolol (Shahzad et al. 2010).

The importance of Cho et al's demonstration of TGFbeta mRNA decreases after dapsone (Cho et al. 2011) meshes nicely with Serizawa et al's demonstration of enhancement of erlotinib's effects on non-small cell lung cancer if TGF-beta is simultaneously inhibited (Serizawa et al. 2013). This also supports a trial of dapsone augmentation of erlotinib.

Adding to the appeal of using dapsone to retard neutrophil migration to cancers are two further aspects. One: In two underappreciated but truly elegant papers, Werther et al. (2002) and Svensen et al. (2004) proved that circulating neutrophils deliver VEGF to rectal cancers. By measuring neutrophil number and VEGF content in the arterial supply and in the venous drainage of these tumors, they found $16 \%$ of VEGF containing neutrophils entering the tumor do not exit it (Werther et al. 2002; Svendsen et al. 2004). Also neutrophils are not just a source of VEGF (Kast et al. 2011, 2012; García-Román and Zentella-Dehesa 2013; Lee et al. 2002) and IL-8- they deliver other growth factors too.

Neutrophils are a prodigious source of multiple other cytokines and growth factors of importance in promoting cancer's growth and treatment resistance (Lee et al. 2002; Scapini et al. 2000; Kasama et al. 2005). Two: During both normal and pathological angiogenesis endothelial IL-8 and neutrophils' IL-8 have an interesting relationship. When endothelium is exposed to IL-8 secreted by neutrophils this awakens and stimulates vessel endothelium to synthesize IL-8, generating a stronger IL-8 gradient along which neutrophils home, bringing yet more IL- 8 to the site, thus forming a feedforward amplification cycle first clearly identified by Garcia-Roman et al. in 2002 (García-Román and Zentella-Dehesa 2013) and (Schruefer et al. 2005).

IL-8 synthesized by keratinocytes after minor wounds attracts neutrophils to the wound (Lan et al. 2013). High ambient glucose, as obtains in diabetes, increases such IL-8 mediated neutrophil migration to wound when neutrophil over-population delays rather than hastens wound healing (Lan et al. 2013). Dapsone normalized wound healing in a diabetic rat model by reducing such excess neutrophil accumulation (Lan et al. 2013).

A little noted breakthrough in understanding glioblastoma pathophysiology came from a study showing that endothelial cells can upregulate their synthesis of IL-8 in response to glioblastoma cells' secreted IL-8, and vice versa (Infanger et al. 2013), findings that replicate the feedforward system of Schruefer et al. (2005) between neutrophils and endothelial cells, findings that again support the potential role for dapsone in glioblastoma treatment.

Glioblastoma (Infanger et al. 2013; Zhang et al. 2015), non-small cell lung cancer (Liu et al. 2015; Khan et al. (2015), ovarian cancer (Wang et al. 2011; Browne et al. 2013; Stronach et al. 2015) and many other cancers' (Sanmamed et al. 2014) cells synthesize IL-8 and express its receptor(s). IL-8 has specifically been recognized as a factor mediating erlotinib resistance in non-small cell lung cancer (Liu et al. 2015). As Zhang et al. suggest, IL-8 would be a "novel therapeutic target for glioma invasion intervention" (Zhang et al. 2015). Dapsone may provide such, resurrecting erlotinib usefulness for glioblastoma and other cancers.

\section{Caveats}

Erlotinib absorption is facilitated by gastric acid so use of proton pump inhibitors should be avoided. Tobacco 
use limits erlotinib absorption so use of all tobacco products must be stopped. Dapsone's primary metabolite N-hydroxydapsone inhibits leukotriene chemotaxis and has other anti-inflammatory attributes (Wozel et al. 1997) of potential benefit during cancer treatment, but not further discussed here.

\section{Conclusions}

This paper reviewed the growth promoting aspects of IL-8 in a few selected cancers and data showing how erlotinib, a drug designed to- and in a limited way succeeded in decreasing cancer growth, can and often does increase IL-8 in skin. The data on neutrophils' sine qua non role in generating the erlotinib rash implies a rash-mitigating role for dapsone. During clinical use in the neutrophilic dermatoses like bullous pemphigoid, dapsone blinds neutrophils to IL- 8 chemotaxis, suggesting by extension that dapsone can ameliorate erlotinib rash, increasing tolerability and quality of life. The tumor growth enhancing effects of IL-8 itself and via neutrophil recruitment to a growing tumor were reviewed. Effects expected to be partially thwarted by dapsone.

Perhaps the most pivotal, telling, and dramatic insight into erlotinib action, and of particular relevance to dapsone augmentation is the recent work of Takashima et al. (Takashima et al. 2012). A cohort of 76 erlotinibtreated (150 mg/day) advanced, previously treated nonsmall cell lung cancer patients developing a rash were divided into two groups-24 whose erlotinib dose was down-titrated to rash mitigation and 31 who were left at the rash-generating dose. Median OS was 566 days in the dose reduction, rash mitigation group but 202 days in the dose maintained, original dose group (Takashima et al. 2012). Such a result would seem to contradict the many studies showing rash as a marginally favorable sign. If dose-related rash mitigation and longer OS is the result of decreasing compensatory IL- 8 drive secondary to decreased erlotinib dose as the reviewed data suggest, then dapsone augmentation may well work by similarly decreasing IL-8 related growth drive and give erlotinib help it clearly needs (Zahonero and Sanchez-Gomez 2014).

\section{Abbreviations}

ET-1: endothelin-1; EGFR: epidermal growth factor receptor; EOC: epithelial ovarian cancer; IL-8: interleukin-8 (synonymous with CXCL8); OS: overall survival; TGF-beta: transforming growth factor-beta; VEGF: vascular endothelial growth factor.

\section{Competing interests}

The author declares that he has no competing interests.

Received: 6 March 2015 Accepted: 14 October 2015

Published online: 23 October 2015

\section{References}

Abe M, Shimizu A, Yokoyama Y, Takeuchi Y, Ishikawa O (2008) A possible inhibitory action of diaminodiphenyl sulfone on tumour necrosis factor-alpha production from activated mononuclear cells on cutaneous lupus erythematosus. Clin Exp Dermatol 33(6):759-763. doi:10.1111/j.1365-2230.2008.02864.x

Aranda E, Manzano JL, Rivera F, Galán M, Valladares-Ayerbes M, Pericay C, Safont MJ, Mendez MJ, Irigoyen A, Arrivi A, Sastre J, Díaz-Rubio E (2012) Phase II open-label study of erlotinib in combination with gemcitabine in unresectable and/or metastatic adenocarcinoma of the pancreas: relationship between skin rash and survival (Pantar study). Ann Oncol 23(7):1919-1925. doi:10.1093/annonc/mdr560

Autelitano DJ, Raineri L, Knight K, Bannister K, Rice GE (2012) Performance of a multianalyte test as an aid for the diagnosis of ovarian cancer in symptomatic women. J TransI Med 10:45. doi:10.1186/1479-5876-10-45

Baggiolini M, Loetscher P, Moser B (1995) Interleukin-8 and the chemokine family. Int J Immunopharmacol 17(2):103-108

Bangsgaard N, Houtkamp M, Schuurhuis DH, Parren PW, Baadsgaard O, Niessen HW, Skov L (2012) Neutralization of IL-8 prevents the induction of dermatologic adverse events associated with the inhibition of epidermal growth factor receptor. PLoS One 7(6):e39706. doi:10.1371/ journal.pone.0039706

Bertenshaw GP, Yip P, Seshaiah P, Zhao J, Chen TH, Wiggins WS, Mapes JP, Mansfield BC (2008) Multianalyte profiling of serum antigens and autoimmune and infectious disease molecules to identify biomarkers dysregulated in epithelial ovarian cancer. Cancer Epidemiol Biomarker Prev. 17(10):2872-2881. doi:10.1158/1055-9965.EPI-08-0464

Bishayee K, Khuda-Bukhsh AR (2013) 5-lipoxygenase antagonist therapy: a new approach towards targeted cancer chemotherapy. Acta Biochim Biophys Sin (Shanghai) 45(9):709. doi:10.1093/abbs/gmt064

Bonavia R, Inda MM, Vandenberg S, Cheng SY, Nagane M, Hadwiger P, Tan P, Sah DW, Cavenee WK, Furnari FB (2012) EGFRvill promotes glioma angiogenesis and growth through the NF-kB, interleukin-8 pathway. Oncogene 31(36):4054-4066. doi:10.1038/onc.2011.563

Booth SA, Moody CE, Dahl MV, Herron MJ, Nelson RD (1992) Dapsone suppresses integrin-mediated neutrophil adherence function. J Invest Dermatol 98(2):135-140

Browne A, Sriraksa R, Guney T, Rama N, Van Noorden S, Curry E, Gabra H, Stronach E, El-Bahrawy M (2013) Differential expression of IL-8 and IL-8 receptors in benign, borderline and malignant ovarian epithelial tumours. Cytokine 64(1):413-421. doi:10.1016/j.cyto.2013.05.006

Campbell LM, Maxwell PJ, Waugh DJ (2013) Rationale and Means to Target Pro-Inflammatory Interleukin-8 (CXCL8) Signaling in Cancer. Pharmaceuticals (Basel) 6(8):929-959. doi:10.3390/ph6080929

Chambers SK, Clouser MC, Baker AF, Roe DJ, Cui H, Brewer MA, Hatch KD, Gordon MS, Janicek MF, Isaacs JD, Gordon AN, Nagle RB, Wright HM, Cohen $J \mathrm{~L}$, Alberts DS (2010) Overexpression of tumor vascular endothelial growth factor A may portend an increased likelihood of progression in a phase II trial of bevacizumab and erlotinib in resistant ovarian cancer. Clin Cancer Res 16(21):5320-5328. doi:10.1158/1078-0432.CCR-10-0974

Chikamatsu K, Takahashi G, Sakakura K, Ferrone S, Masuyama K (2011) Immunoregulatory properties of CD44+ cancer stem-like cells in squamous cell carcinoma of the head and neck. Head Neck 33(2):208-215. doi:10.1002/hed.21420

Cho SC, Rhim JH, Choi HR, Son YH, Lee SJ, Song KY, Park SC (2011) Protective effect of 4,4'-diaminodiphenylsulfone against paraquat-induced mouse lung injury. Exp Mol Med 43(9):525-537

Cohen PR (2009) Neutrophilic dermatoses: a review of current treatment options. Am J Clin Dermatol 10(5):301-312. doi:10.2165/11310730-000000000-00000

Coleman MD (1993) Dapsone: modes of action, toxicity and possible strategies for increasing patient tolerance. Br J Dermatol 129:507-513

D'Arcangelo M, Cappuzzo F (2013) Erlotinib in the first-line treatment of non-small-cell lung cancer. Expert Rev Anticancer Ther 13(5):523-533. doi:10.1586/era.13.23

Davidson B, Goldberg I, Gotlieb WH, Kopolovic J, Risberg B, Ben-Baruch G, Reich R (2003) Coordinated expression of integrin subunits, matrix metalloproteinases (MMP), angiogenic genes and Ets transcription factors in advanced-stage ovarian carcinoma: a possible activation pathway? Cancer Metastasis Rev 22(1):103-115 
Desbaillets I, Diserens AC, Tribolet N, Hamou MF, Van Meir EG (1997) Upregulation of interleukin-8 by oxygen-deprived cells in glioblastoma suggests a role in leukocyte activation, chemotaxis, and angiogenesis. J Exp Med 186(8):1201-1212

Dobrzycka B, Mackowiak-Matejczyk B, Terlikowska KM, Kulesza-Bronczyk B, Kinalski M, Terlikowski SJ (2013) Serum levels of IL-6, IL-8 and CRP as prognostic factors in epithelial ovarian cancer. Eur Cytokine Netw 24(3):106-113. doi:10.1684/ecn.2013.0340

Dong H, Zhang Y, Xi H (2012) The effects of epidural anaesthesia and analgesia on natural killer cell cytotoxicity and cytokine response in patients with epithelial ovarian cancer undergoing radical resection. J Int Med Res 40(5):1822-1829

Fang KM, Wang YL, Huang MC, Sun SH, Cheng H, Tzeng SF (2011) Expression of macrophage inflammatory protein-1 $a$ and monocyte chemoattractant protein-1 in glioma-infiltrating microglia: involvement of ATP and P2X receptor. J Neurosci Res 89(2):199-211. doi:10.1002/jnr.22538

Fiala O, Pesek M, Finek J, Krejci J, Ricar J, Bortlicek Z, Benesova L, Minarik M (2013) Skin rash as useful marker of erlotinib efficacy in NSCLC and its impact on clinical practice. Neoplasma 60(1):26-32. doi:10.4149/ neo_2013_004

Fukudo M, Ikemi Y, Togashi Y, Masago K, Kim YH, Mio T, Terada T, Teramukai S, Mishima M, Inui K, Katsura T (2013) Population pharmacokinetics/pharmacodynamics of erlotinib and pharmacogenomic analysis of plasma and cerebrospinal fluid drug concentrations in Japanese patients with non-small cell lung cancer. Clin Pharmacokinet 52(7):593-609. doi:10.1007/s40262-013-0058-5

Gales D, Clark C, Manne U, Samuel T (2013) The chemokine CXCL8 in carcinogenesis and drug response. ISRN Oncol 2013:859154

García-Román J, Zentella-Dehesa A (2013) Vascular permeability changesinvolved in tumor metastasis. Cancer Lett 335(2):259-269. doi:10.1016/j. canlet.2013.03.005

Gross ND, Bauman JE, Gooding WE, Denq WH, Thomas SM, Wang L, Chiosea S, Hood BL, Flint MS, Sun M, Conrads TP, Ferris RL, Johnson JT, Kim S, Argiris A, Wirth LJ, Nikiforova MN, Siegfried JM, Grandis JR (2014) Erlotinib, erlotinib-sulindac vs. placebo: a randomized, doubleblind, placebo-controlled window trial in operable head and neck cancer. Clin Cancer Res 20(12):3289-3298. doi:10.1158/1078-0432. CCR-13-3360

Hau P, Jachimczak P, Schlaier J, Bogdahn U (2011) TGF- 32 signaling in highgrade gliomas. Curr Pharm Biotechnol 12(12):2150-2157

Infanger DW, Cho Y, Lopez BS, Mohanan S, Liu SC, Gursel D, Boockvar JA, Fischbach C (2013) Glioblastoma stem cells are regulated by interleukin-8 signaling in a tumoral perivascular niche. Cancer Res 73(23):7079-7089. doi:10.1158/0008-5472.CAN-13-1355

Ishii K, Zaitsu M, Yonemitsu N, Kan Y, Hamasaki Y, Matsuo M (2009) 5-lipoxygenase pathway promotes cell proliferation in human glioma cell lines. Clin Neuropathol 28(6):445-452

Jia Y, Lacouture ME, Su X, Wu S (2009) Risk of skin rash associated with erlotinib in cancer patients: a meta-analysis. J Support Oncol 7(6):211-217

Joseph JV, Balasubramaniyan V, Walenkamp A, Kruyt FA (2013) TGF- $\beta$ as a therapeutic target in high grade gliomas - promises and challenges. Biochem Pharmacol 85(4):478-485. doi:10.1016/j.bcp.2012.11.005

Kaburagi T, Satoh H, Hayashihara K, Endo T, Hizawa N, Kurishima K, Nishimura Y, Hashimoto T, Nakamura H, Kishi K, Inagaki M, Nawa T, Ichimura H, Ishikawa H, Kagohashi K, Fukuoka T, Shinohara Y, Kamiyama K, Sato Y, Sakai M, Matsumura T, Uchiumi K, Furukawa K (2013) Observational study on the efficacy and safety of erlotinib in patients with non-small cell lung cancer. Oncol Lett 5(2):435-439

Kang SH, Chess-Williams R, Anoopkumar-Dukie S, McDermott C (2013) Induction of inflammatory cytokines and alteration of urothelial ATP, acetylcholine and prostaglandin E2 release by doxorubicin. Eur J Pharmacol 700(1-3):102-109. doi:10.1016/j.ejphar.2012.11.053

Kanoh S, Tanabe T, Rubin BK (2011) Dapsone inhibits IL-8 secretion from human bronchial epithelial cells stimulated with lipopolysaccharide and resolves airway inflammation in the ferret. Chest 140(4):980-990. doi:10.1378/chest.10-2908

Kasama T, Miwa Y, Isozaki T, Odai T, Adachi M, Kunkel SL (2005) Neutrophilderived cytokines: potential therapeutic targets in inflammation. Curr Drug Target Inflamm Allergy 4(3):273-279

Kasperkiewicz M, Zillikens D (2007) The pathophysiology of bullous pemphigoid. Clin Rev Allergy Immunol 33:67-77
Kassim SK, El-Salahy EM, Fayed ST, Helal SA, Helal T (2004) Azzam Eel-D, Khalifa A. Vascular endothelial growth factor and interleukin-8 are associated with poor prognosis in epithelial ovarian cancer patients. Clin Biochem 37(5):363-369

Kast RE (2009) Endothelin-1 inhibition by ambrisentan as a potential treatment adjunct after debulking surgery in epithelial ovarian cancer. Oncol Res 17(8):383-386

Kast RE, Scheuerle A, Wirtz CR, Karpel-Massler G, Halatsch ME (2011) The rationale of targeting neutrophils with dapsone during glioblastoma treatment. Anticancer Agent Med Chem 11(8):756-761

Kast RE, Lefranc F, Karpel-Massler G, Halatsch ME (2012) Why dapsone stops seizures and may stop neutrophils' delivery of VEGF to glioblastoma. $\mathrm{Br}$ J Neurosurg 26(6):813-817. doi:10.3109/02688697.2012.674577

Kesavabhotla K, Schlaff CD, Shin B, Mubita L, Kaplan R, Tsiouris AJ, Pannullo SC, Christos P, Lavi E, Scheff R, Boockvar JA (2012) Phase I/II study of oral erlotinib for treatment of relapsed/refractory glioblastoma multiforme and anaplastic astrocytoma. J Exp Ther Oncol 10(1):71-81

Khan MN, Wang B, Wei J, Zhang Y, Li Q, Luan X, Cheng JW, Gordon JR, Li F, Liu H (2015) CXCR1/2 antagonism with CXCL8/Interleukin-8 analogue CXCL8(3-72)K11R/G31P restricts lung cancer growth by inhibiting tumor cell proliferation and suppressing angiogenesis. Oncotarget 6(25):21315-21327

Kiyohara Y, Yamazaki N, Kishi A (2013) Erlotinib-related skin toxicities: treatment strategies in patients with metastatic non-small cell lung cancer. J Am Acad Dermatol 69(3):463-472. doi:10.1016/j.jaad.2013.02.025

Lan CC, Wu CS, Huang SM, Wu IH, Chen GS (2013) High-glucose environment enhanced oxidative stress and increased interleukin-8 secretion from keratinocytes: new insights into impaired diabetic wound healing. Diabetes 62(7):2530-2538. doi:10.2337/db12-1714

Lee TH, Avraham H, Lee SH, Avraham S (2002) Vascular endothelial growth factor modulates neutrophil transendothelial migration via up-regulation of interleukin-8 in human brain microvascular endothelial cells. J Biol Chem 277(12):10445-10451

Lippitz BE (2013) Cytokine patterns in patients with cancer: a systematic review. Lancet Oncol 14(6):e218-e228. doi:10.1016/ S1470-2045(12)70582-X

Liu Y, Ye F, Yamada K, Tso JL, Zhang Y, Nguyen DH, Dong Q, Soto H, Choe J, Dembo A, Wheeler H, Eskin A, Schmid I, Yong WH, Mischel PS, Cloughesy TF, Kornblum HI, Nelson SF, Liau LM, Tso CL (2011) Autocrine endothelin-3/endothelin receptor $B$ signaling maintains cellular and molecular properties of glioblastoma stem cells. Mol Cancer Res 9(12):1668-1685. doi:10.1158/1541-7786.MCR-10-0563

Liu YN, Chang TH, Tsai MF, Wu SG, Tsai TH, Chen HY, Yu SL, Yang JC, Shih JY (2015) IL-8 confers resistance to EGFR inhibitors by inducing stem cell properties in lung cancer. Oncotarget 6(12):10415-10431

Lokshin AE, Winans M, Landsittel D, Marrangoni AM, Velikokhatnaya L, Modugno F, Nolen BM, Gorelik E (2006) Circulating IL-8 and antiIL-8 autoantibody in patients with ovarian cancer. Gynecol Oncol 102(2):244-251

López R, Méndez CM, Fernández MJ, Reinoso CR, Aldana GQ, Fernández MS, DE LA Cámara Gómez J, López MR, Vázquez MR, Folgar SC (2013) Phase II trial of erlotinib plus capecitabine as first-line treatment for metastatic pancreatic cancer (XELTA study). Anticancer Res 33(2):717-723

Luo Y, Ellis LZ, Dallaglio K, Takeda M, Robinson WA, Robinson SE, Liu W, Lewis KD, McCarter MD, Gonzalez R, Norris DA, Roop DR, Spritz RA, Ahn NG, Fujita M (2012) Side population cells from human melanoma tumors reveal diverse mechanisms for chemoresistance. J Invest Dermatol 132(10):2440-2450. doi:10.1038/jid.2012.161

Ma Z, Zhang T, Wang R, Cheng Z, Xu H, Li W, Wang Y, Wang X (2011) Tissue factor-factor VIla complex induces epithelial ovarian cancer cell invasion and metastasis through a monocytes-dependent mechanism. Int J Gynecol Cancer 21(4):616-624. doi:10.1097/IGC.0b013e3182150e98

Meng Z, Cao R, Yang Z, Liu T, Wang Y, Wang X (2013) Inhibitor of 5-lipoxygenase, zileuton, suppresses prostate cancer metastasis by upregulating E-cadherin and paxillin. Urology 82(6):1452.e7-1452.e14. doi:10.1016/j. urology.2013.08.060

Merighi S, Simioni C, Gessi S, Varani K, Mirandola P, Tabrizi MA, Baraldi PG, Borea PA (2009) A(2B) and A(3) adenosine receptors modulate vascular endothelial growth factor and interleukin-8 expression in human melanoma cells treated with etoposide and doxorubicin. Neoplasia 11(10):1064-1073 
Merritt WM, Lin YG, Spannuth WA, Fletcher MS, Kamat AA, Han LY, Landen CN, Jennings N, De Geest K, Langley RR, Villares G, Sanguino A, Lutgendorf SK, Lopez-Berestein G, Bar-Eli MM, Sood AK (2008) Effect of interleukin-8 gene silencing with liposome-encapsulated small interfering RNA on ovarian cancer cell growth. J Natl Cancer Inst 100(5):359-372. doi:10.1093/jnci/djn024

Morin P Jr, Ferguson D, LeBlanc LM, Hébert MJ, Paré AF, Jean-François J, Surette ME, Touaibia M, Cuperlovic-Culf M (2013) NMR metabolomics analysis of the effects of 5-lipoxygenase inhibitors on metabolism in glioblastomas. J Proteome Res 12(5):2165-2176. doi:10.1021/pr400026q

Nardone B, Nicholson K, Newman M, Guitart J, Gerami P, Talarico N, Yang XJ, Rademaker A, West DP, Lacouture ME (2010) Histopathologic and immunohistochemical characterization of rash to human epidermal growth factor receptor 1 (HER1) and HER1/2 inhibitors in cancer patients. Clin Cancer Res 16(17):4452-4460. doi:10.1158/1078-0432. CCR-10-0421

Nieman KM, Kenny HA, Penicka CV, Ladanyi A, Buell-Gutbrod R, Zillhardt MR, Romero IL, Carey MS, Mills GB, Hotamisligil GS, Yamada SD, Peter ME, Gwin K, Lengyel E (2011) Adipocytes promote ovarian cancer metastasis and provide energy for rapid tumor growth. Nat Med 17(11):14981503. doi:10.1038/nm.2492

Opravil M, Joos B, Lüthy R (1994) Levels of dapsone and pyrimethamine in serum uring once-weekly dosing for prophylaxis of Pneumocystis carinii pneumonia and toxoplasmic encephalitis. Antimicrob Agents Chemother 38(5):1197-1199

Pallis AG, Syrigos KN (2013) Epidermal growth factor receptor tyrosine kinase inhibitors in the treatment of NSCLC. Lung Cancer 80(2):120-130. doi:10.1016/j.lungcan.2012.12.025

Paniker U, Levine N (2001) Dapsone and sulfapyridine. Dermatol Clin 19(1):79-86 (viii)

Paolillo M, Russo MA, Curti D, Lanni C, Schinelli S (2010) Endothelin B receptor antagonists block proliferation and induce apoptosis in glioma cells. Pharmacol Res 61(4):306-315. doi:10.1016/j.phrs.2009.11.003

Park S, Chung MJ, Park JY, Chung JB, Bang S, Park SW, Song SY (2013) Phase II trial of erlotinib plus gemcitabine chemotherapy in Korean patients with advanced pancreatic cancer and prognostic factors for chemotherapeutic response. Gut Liver 7(5):611-615. doi:10.5009/ gnl.2013.7.5.611

Patel T, McKeage K (2014) Macitentan: first global approval. Drugs 74(1):127133. doi:10.1007/s40265-013-0156-6

Peereboom DM, Shepard DR, Ahluwalia MS, Brewer CJ, Agarwal N, Stevens GH, Suh JH, Toms SA, Vogelbaum MA, Weil RJ, Elson P, Barnett GH (2010) Phase II trial of erlotinib with temozolomide and radiation in patients with newly diagnosed glioblastoma multiforme. J Neurooncol 98(1):9399. doi:10.1007/s11060-009-0067-2

Petrelli F, Borgonovo K, Cabiddu M, Lonati V, Barni S (2012) Relationship between skin rash and outcome in non-small-cell lung cancer patients treated with anti-EGFR tyrosine kinase inhibitors: a literature-based meta-analysis of 24 trials. Lung Cancer 78(1):8-15. doi:10.1016/j. lungcan.2012.06.009

Piette EW, Werth VP (2012) Dapsone in the management of autoimmune bullous diseases. Immunol Allergy Clin North Am 32(2):317-322. doi:10.1016/j.iac.2012.04.011 (vii)

Pruthi RS, Nielsen M, Heathcote S, Wallen EM, Rathmell WK, Godley P, Whang Y, Fielding J, Schultz H, Grigson G, Smith A, Kim W (2010) A phase II trial of neoadjuvant erlotinib in patients with muscle-invasive bladder cancer undergoing radical cystectomy: clinical and pathological results. BJU Int 106(3):349-354. doi:10.1111/j.1464-410X.2009.09101.x

Qaddoumi I, Kocak M, Pai Panandiker AS, Armstrong GT, Wetmore C, Crawford JR, Lin T, Boyett JM, Kun LE, Boop FA, Merchant TE, Ellison DW, Gajjar A, Broniscer A (2014) Phase II trial of erlotinib during and after radiotherapy in children with newly diagnosed high-grade gliomas. Front Oncol 4:67. doi:10.3389/fonc.2014.00067

Raizer JJ, Abrey LE, Lassman AB, Chang SM, Lamborn KR, Kuhn JG, Yung WK, Gilbert MR, Aldape KA, Wen PY, Fine HA, Mehta M, Deangelis LM, Lieberman F, Cloughesy TF, Robins HI, Dancey J, Prados MD (2010) North American Brain Tumor Consortium. A phase II trial of erlotinib inpatients with recurrent malignant gliomas and non-progressive glioblastoma multiforme postradiation therapy. Neuro Oncol 12(1):95-103. doi:10.1093/neuonc/nop015
Reers S, Pfannerstill AC, Rades D, Maushagen R, Andratschke M, Pries R, Wollenberg B (2013) Cytokine changes in response to radio-/chemotherapeutic treatment in head and neck cancer. Anticancer Res 33(6):2481-2489

Rich JD, Mirochnick M (1996) Dapsone penetrates cerebrospinal fluid during Pneumocystis carinii pneumonia prophylaxis. Diagn Microbiol Infect Dis 24(2):77-79

Rozensztajn N, Ruppert AM, Lavole A, Leprieur EG, Duruisseaux M, Vieira T, Rabbe N, Lacave R, Antoine M, Cadranel J, Wislez M (2014) Factors associated with early progression of non-small-cell lung cancer treated by epidermal growth factor receptor tyrosine-kinase inhibitors. Cancer Med 3(1):61-69. doi:10.1002/cam4.180

Sanmamed MF, Carranza-Rua O, Alfaro C, Onate C, Marti-n-Algarra S, Perez G, Landazuri SF, Gonzalez A, Gross S, Rodriguez I, Munoz-Calleja C, Rodriguez-Ruiz M, Sangro B, Lopez-Picazo JM, Rizzo M, Mazzolini G, Pascual Jl, Andueza MP, Perez-Gracia JL, Melero I (2014) Serum interleukin-8 reflects tumor burden and treatment response across malignancies of multiple tissue origins. Clin Cancer Res 20(22):5697-5707. doi:10.1158/1078-0432.CCR-13-3203

Scapini P, Lapinet-Vera JA, Gasperini S, Calzetti F, Bazzoni F, Cassatella MA (2000) The neutrophil as a cellular source of chemokines. Immunol Rev 177:195-203

Schmidt E, Reimer S, Kruse N, Bröcker EB, Zillikens D (2001) The IL-8 release from c ultured human keratinocytes, mediated by antibodies to bullous pemphigoid autoantigen 180, is inhibited by dapsone. Clin Exp Immunol 124(1):157-162

Schruefer R, Lutze N, Schymeinsky J, Walzog B (2005) Human neutrophils promote angiogenesis by a paracrine feedforward mechanism involving endothelial interleukin-8. Am J Physiol Heart Circ Physiol 288:H1186-H1192

Serizawa M, Takahashi T, Yamamoto N, Koh Y (2013) Combined treatment with erlotinib and a transforming growth factor- $\beta$ type I receptor inhibitor effectively suppresses the enhanced motility of erlotinib-resistant nonsmall-cell lung cancer cells. J Thorac Oncol 8(3):259-269. doi:10.1097/ JTO.0b013e318279e9104

Shahzad MM, Arevalo JM, Armaiz-Pena GN, Lu C, Stone RL, Moreno-Smith M, Nishimura M, Lee JW, Jennings NB, Bottsford-Miller J, Vivas-Mejia P, Lutgendorf SK, Lopez-Berestein G, Bar-Eli M, Cole SW, Sood AK (2010) Stress effects on FosB- and interleukin-8 (IL8)-driven ovarian cancer growth and metastasis. J Biol Chem 285(46):35462-35470. doi:10.1074/ jbc.M110.109579

Shi Q, Xiong Q, Le X, Xie K (2001) Regulation of interleukin-8 expression by tumor-associated stress factors. J Interferon Cytokine Res 21(8):553-566

Shimanovich I, Mihai S, Oostingh GJ, Ilenchuk TT, Brocker EB, Opdenakker G, Zillikens D, Sitaru C (2004) Granulocyte-derived elastase and gelatinase $B$ are required for dermal-epidermal separation induced by autoantibodies from patients with epidermolysis bullosa acquisita and bullous pemphigoid. J Pathol 204:519-527

Singh JK, Simões BM, Howell SJ, Farnie G, Clarke RB (2013a) Recent advances reveal IL-8 signaling as a potential key to targeting breast cancer stem cells. Breast Cancer Res 15(4):210

Singh JK, Farnie G, Bundred NJ, Simões BM, Shergill A, Landberg G, Howell SJ, Clarke RB (2013b) Targeting CXCR1/2 significantly reduces breast cancer stem cell activity and increases the efficacy of inhibiting HER2 via HER2-dependent and independent mechanisms. Clin Cancer Res 19(3):643-656. doi:10.1158/1078-0432.CCR-12-1063

Stepanski EJ, Reyes C, Walker MS, Satram-Hoang S, Leon L, Wojtowicz-Praga S, Miller PJ, Houts AC, Schwartzberg LS (2013) The association of rash severity with overall survival: findings from patients receiving erlotinib for pancreatic cancer in the community setting. Pancreas 42(1):32-36. doi:10.1097/MPA.0b013e318254f19a

Stiles JD, Ostrow PT, Balos LL, Greenberg SJ, Plunkett R, Grand W, Heffner RR Jr (1997) Correlation of endothelin-1 and transforming growth factor beta 1 with malignancy and vascularity in human gliomas. J Neuropathol Exp Neurol 56(4):435-439

Stronach EA, Cunnea P, Turner C, Guney T, Aiyappa R, Jeyapalan S, de Sousa CH, Browne A, Magdy N, Studd JB, Sriraksa R, Gabra H, El-Bahrawy M (2015) The role of interleukin-8 (IL-8) and IL-8 receptors in platinum response in high grade serous ovarian carcinoma. Oncotarget 6(31):31593-31603 
Svendsen MN, Lykke J, Werther K, Christensen IJ, Nielsen HJ (2004) Concentrations of VEGF and VEGFR1 in paired tumor arteries and veins in patients with rectal cancer. Oncol Res 14(11-12):611-615

Swain AF, Ahmad RA, Rogers HJ, Leonard JN, Fry L (1983) Pharmacokinetic observations on dapsone in dermatitis herpetiformis. Br J Dermatol 108(1):91-98

Takashima N, Kimura T, Watanabe N, Umemura T, Katsuno S, Arakawa K, Fukatsu M, Nakamura N, Nishiyama O, Kataoka K, Kondoh Y, Taniguchi $H$ (2012) Prognosis in patients with non-small cell lung cancer who received erlotinib treatment and subsequent dose reduction due to skin rash. Onkologie 35(12):747-752. doi:10.1159/000345039

Tan EH, Chan A (2009) Evidence-based treatment options for the management of skin toxicities associated with epidermal growth factor receptor inhibitors. Ann Pharmacother 43(10):1658-1666. doi:10.1345/ aph.1M241

Tang KH, Ma S, Lee TK, Chan YP, Kwan PS, Tong CM, Ng IO, Man K, To KF, Lai PB, Lo CM, Guan XY, Chan KW (2012) CD133(+) liver tumor-initiating cells promote tumor angiogenesis, growth, and self-renewal through neurotensin/interleukin-8/CXCL1 signaling. Hepatology 55(3):807-820 doi:10.1002/hep.24739

Tiseo M, Andreoli R, Gelsomino F, Mozzoni P, Azzoni C, Bartolotti M, Bortesi B, Goldoni M, Silini EM, De Palma G, Mutti A, Ardizzoni A (2014) Correlation between erlotinib pharmacokinetics, cutaneous toxicity and clinical outcomes in patients with advanced non-small cell lung cancer (NSCLC). Lung Cancer 83(2):265-271. doi:10.1016/j.lungcan.2013.12.001

Vaccaro V, Bria E, Sperduti I, Gelibter A, Moscetti L, Mansueto G, Ruggeri EM, Gamucci T, Cognetti F, Milella M (2013) First-line erlotinib and fixed dose-rate gemcitabine for advanced pancreatic cancer. World J Gastroenterol 19(28):4511-4519. doi:10.3748/wjg.v19.i28.4511

Van Meerbeeck J, Galdermans D, Bustin F, De Vos L, Lechat I, Abraham I (2014) Survival outcomes in patients with advanced non-small cell lung cancer treated with erlotinib: expanded access programme data from Belgium (the TRUST study). Eur J Cancer Care (Engl) 23(3):370-379. doi:10.1111/ecc.12146

Vergara D, Merlot B, Lucot JP, Collinet P, Vinatier D, Fournier I, Salzet M (2010) Epithelial-mesenchymal transition in ovarian cancer. Cancer Lett 291(1):59-66. doi:10.1016/j.canlet.2009.09.017

Wallach D, Vignon-Pennamen MD (2006) From acute febrile neutrophilic dermatosis to neutrophilic disease: forty years of clinical research. J Am Acad Dermatol 55(6):1066-1071

Wan S, Pestka S, Jubin RG, Lyu YL, Tsai YC, Liu LF (2012) Chemotherapeutics and radiation stimulate MHC class I expression through elevated interferon-beta signaling in breast cancer cells. PLoS One 7(3):e32542. doi:10.1371/journal.pone.0032542

Wang Y, Yang J, Gao Y, Du Y, Bao L, Niu W, Yao Z (2005) Regulatory effect of e2, IL-6 and IL-8 on the growth of epithelial ovarian cancer cells. Cell Mol Immunol 2(5):365-372

Wang Y, Qu Y, Niu XL, Sun WJ, Zhang XL, Li LZ (2011) Autocrine production of interleukin-8 confers cisplatin and paclitaxel resistance in ovarian cancer cells. Cytokine 56(2):365-375. doi:10.1016/j.cyto.2011.06.005

Wang Y, Xu RC, Zhang XL, Niu XL, Qu Y, Li LZ, Meng XY (2012) Interleukin-8 secretion by ovarian cancer cells increases anchorage-independent growth, proliferation, angiogenic potential, adhesion and invasion. Cytokine 59(1):145-155. doi:10.1016/j.cyto.2012.04.013

Wang X, Zhao X, Wang K, Wu L, Duan T (2013) Interaction of monocytes/ macrophages with ovarian cancer cells promotes angiogenesis in vitro. Cancer Sci 104(4):516-523. doi:10.1111/cas.12110

Weigert A, Sekar D, Brüne B (2009) Tumor-associated macrophages as targets for tumor immunotherapy. Immunotherapy 1(1):83-95. doi:10.2217/17 $50743 \times .1 .1 .83$

Wen PY, Chang SM, Lamborn KR, Kuhn JG, Norden AD, Cloughesy TF, Robins HI, Lieberman FS, Gilbert MR, Mehta MP, Drappatz J, Groves MD, Santagata S, Ligon AH, Yung WK, Wright JJ, Dancey J, Aldape KD, Prados MD, Ligon KL (2014) Phase I/II study of erlotinib and temsirolimus for patients with recurrent malignant gliomas: North American Brain Tumor Consortium trial 04-02. Neuro Oncol 16(4):567-578. doi:10.1093/neuonc/not247
Wen Z, Liu H, Li M, Li B, Gao W, Shao Q, Fan B, Zhao F, Wang Q, Xie Q, Yang Y, Yu J, Qu X (2015) Increased metabolites of 5-lipoxygenase from hypoxic ovarian cancer cells promote tumor-associated macrophage infiltration. Oncogene 34(10):1241-1252. doi:10.1038/onc.2014.85

Werther K, Bülow S, Hesselfeldt P, Jespersen NF, Svendsen MN, Nielsen HJ (2002) VEG F concentrations in tumour arteries and veins from patients with rectal cancer. APMIS 110(9):646-650

Wilson C, Wilson T, Johnston PG, Longley DB, Waugh DJ (2008a) Interleukin-8 signaling attenuates TRAIL- and chemotherapy-induced apoptosis through transcriptional regulation of c-FLIP in prostate cancer cells. Mol Cancer Ther 7(9):2649-2661. doi:10.1158/1535-7163.MCT-08-0148

Wilson C, Purcell C, Seaton A, Oladipo O, Maxwell PJ, O'Sullivan JM, Wilson RH, Johnston PG, Waugh DJ (2008b) Chemotherapy-induced CXCchemokine/CXC-chemokine receptor signaling in metastatic prostate cancer cells confers resistance to oxaliplatin through potentiation of nuclear factor-kappaB transcription and evasion of apoptosis. J Pharmacol Exp Ther 327(3):746-759. doi:10.1124/jpet.108.143826

Wozel G, Blasum C (2014) Dapsone in dermatology and beyond. Arch Dermatol Res 306(2):103-124. doi:10.1007/s00403-013-1409-7

Wozel G, Lehmann B (1995) Dapsone inhibits the generation of 5-lipoxygenase products in human polymorphonuclear leukocytes. Skin Pharmacol 8(4):196-202

Wozel G, Blasum C, Winter C, Gerlach B (1997) Dapsone hydroxylamine inhibits the LTB4-induced chemotaxis of polymorphonuclear leukocytes into human skin: results of a pilot study. Inflamm Res 46(10):420-422

Yalon M, Rood B, MacDonald TJ, McCowage G, Kane R, Constantini S, Packer RJ (2013) A feasibility and efficacy study of rapamycin and erlotinib for recurrent pediatric low-grade glioma (LGG). Pediatr Blood Cancer 60(1):71-76. doi:10.1002/pbc.24142

Yang G, Rosen DG, Liu G, Yang F, Guo X, Xiao X, Xue F, Mercado-Uribe I, Huang J, Lin SH, Mills GB, Liu J (2010) CXCR2 promotes ovarian cancer growth through dysregulated cell cycle, diminished apoptosis, and enhanced angiogenesis. Clin Cancer Res 16(15):3875-3886. doi:10.1158/10780432.CCR-10-0483

Yung WK, Vredenburgh JJ, Cloughesy TF, Nghiemphu P, Klencke B, Gilbert MR, Reardon DA, Prados MD (2010) Safety and efficacy of erlotinib in first-relapse glioblastoma: a phase II open-label study. Neuro Oncol 12(10):1061-1070. doi:10.1093/neuonc/noq072

Zahonero C, Sanchez-Gomez P (2014) EGFR-dependent mechanisms in glioblastoma: towards a better therapeutic strategy. Cell Mol Life Sci 71(18):3465-3488. doi:10.1007/s00018-014-1608-1

Zhang J, Zhang W, Huang S, Li H, Li Y, Chen H, Wu W, Zhou W, Wang C, Liao $H$, Gu L (2012) Maintenance erlotinib improves clinical outcomes of unresectable advanced non-small cell lung cancer: a meta-analysis of randomized controlled trials. Exp Ther Med 4(5):849-858

Zhang B, Shi L, Lu S, Sun X, Liu Y, Li H, Wang X, Zhao C, Zhang H, Wang Y (2015) Autocrine IL-8 Promotes F-actin Polymerization and mediate mesenchymal transition via ELMO1-NF-kB-Snail signalling in glioma. Cancer Biol Ther 16(6):898-911

Zuidema J, Hilbers-Modderman ES, Merkus FW (1986) Clinical pharmacokinetics of dapsone. Clin Pharmacokinet 11(4):299-315

\section{Submit your manuscript to a SpringerOpen ${ }^{\circ}$ journal and benefit from:}

- Convenient online submission

- Rigorous peer review

- Immediate publication on acceptance

- Open access: articles freely available online

- High visibility within the field

- Retaining the copyright to your article

Submit your next manuscript at springeropen.com 